 Social Development
}

Vol. 2, No. 1, pp. 37-49, 2021

\section{Effect of Selected Economic Sectors on Poverty}

\author{
Cut Miranda Pusra*, Srinita and Chenny Seftarita \\ Faculty of Economics and Business, Syiah Kuala University, Jl.Teuku Nyak Arief, Darussalam, Banda Aceh, Indonesia.
}

*Corresponding author email: cutpusra@mhs.unsyiah.ac.id,

\begin{abstract}
This study analyzes the influence of certain economic sectors on poverty levels in districts/cities in Aceh Province. The determination of the economic sector is based on the 4 largest contributions to the economy in Aceh. The economic sector in question is the agriculture, trade, construction, and processing industry sectors. So that the purpose of this study is to analyze the influence of selected economic sectors, namely the agricultural sector, the trade sector, the construction sector, and the manufacturing sector on poverty levels in Aceh. This study uses panel data from 23 districts/cities in Aceh Province for the period 2010-2019 and the data used is the percentage of poverty and data on the distribution of the percentage of Gross Regional Domestic Product (GRDP) by business field. The results obtained from this study are that all independent variables, namely the agricultural sector, the trade sector, the construction sector, and the manufacturing sector have a significant negative effect on the poverty level. This can be seen from the $\mathrm{F}$ test probability of 0.00 . Partially the agricultural sector reduced the poverty rate by $0.71 \%$. Trade sector $0.48 \%$. The construction sector reduces poverty by $0.51 \%$ and the manufacturing sector reduces poverty by $0.67 \%$. Therefore, it is hoped that the government can work together with other policymakers to improve the manufacturing sector both in agriculture and other fields to increase the productivity of society to alleviate poverty.
\end{abstract}

Keywords: Poverty, economic sector, Panel Data Regression, and Aceh Province.

\section{Introduction}

Economic development is inseparable from several problems such as increasing the Gross Domestic Product (GDP), reducing the income gap, and reducing the number of poor people (Christiaensen and Kuhl, 2011). Besides that, sometimes it becomes a dilemma between economic improvement and poverty because the increase in high economic growth does not always guarantee income inequality and the number of poor people will also be low (Sehrawat and Giri, 2016). Todaro stated that persistent poverty coupled with high rates is at the core of all development problems (Pérez de la Fuente, B, 2016). Poverty can be categorized as a multidimensional problem that is closely related to aspects of people's lives in terms of politics, economy, technology, psychology, society \& culture, as well as other aspects that are interrelated with each other (Setyo and Lilik, 2016).

But on the other hand, the World Bank also views that poverty includes not only material (the concept of measuring income or proper consumption) but also low education and health attainment. Objectively, poverty alleviation is the main goal of foreign aid flows (Arham et al., 2020).

Furthermore, foreign aid on concession terms is usually channeled either directly or indirectly through multilateral agencies or private voluntary organizations to enhance the country's social and economic development (Singh, P. K., and Chudasama, 2020). Poverty alleviation efforts need time and the right strategy, as well as resources that need to be synergized to overcome this problem (Nargis, 2019).

Aceh is one of the provinces in Indonesia which has a poverty rate that always decreases every year but even though it has a downward trend, the poverty rate in Aceh is still in the above position compared to other provinces on the island of Sumatra (Zakaria $d k k ., 2019$ ).

The relatively declining poverty rate is a reflection of the efforts that have been made by the Aceh Provincial Government to reduce poverty levels through various poverty reduction programs that are continuously carried out every year. However, the decline in the poverty rate continues to slow down every year. 2016 amounted to $16.43 \%$. Then it decreased in 2017 to $15.92 \%$ but Aceh became the province with the highest poverty rate. Furthermore, the 
same thing happened in 2018 and 2019. In 2020 Aceh returned to the second-highest poverty position in Aceh as it was in 2016. This can be seen in the following figure 1:

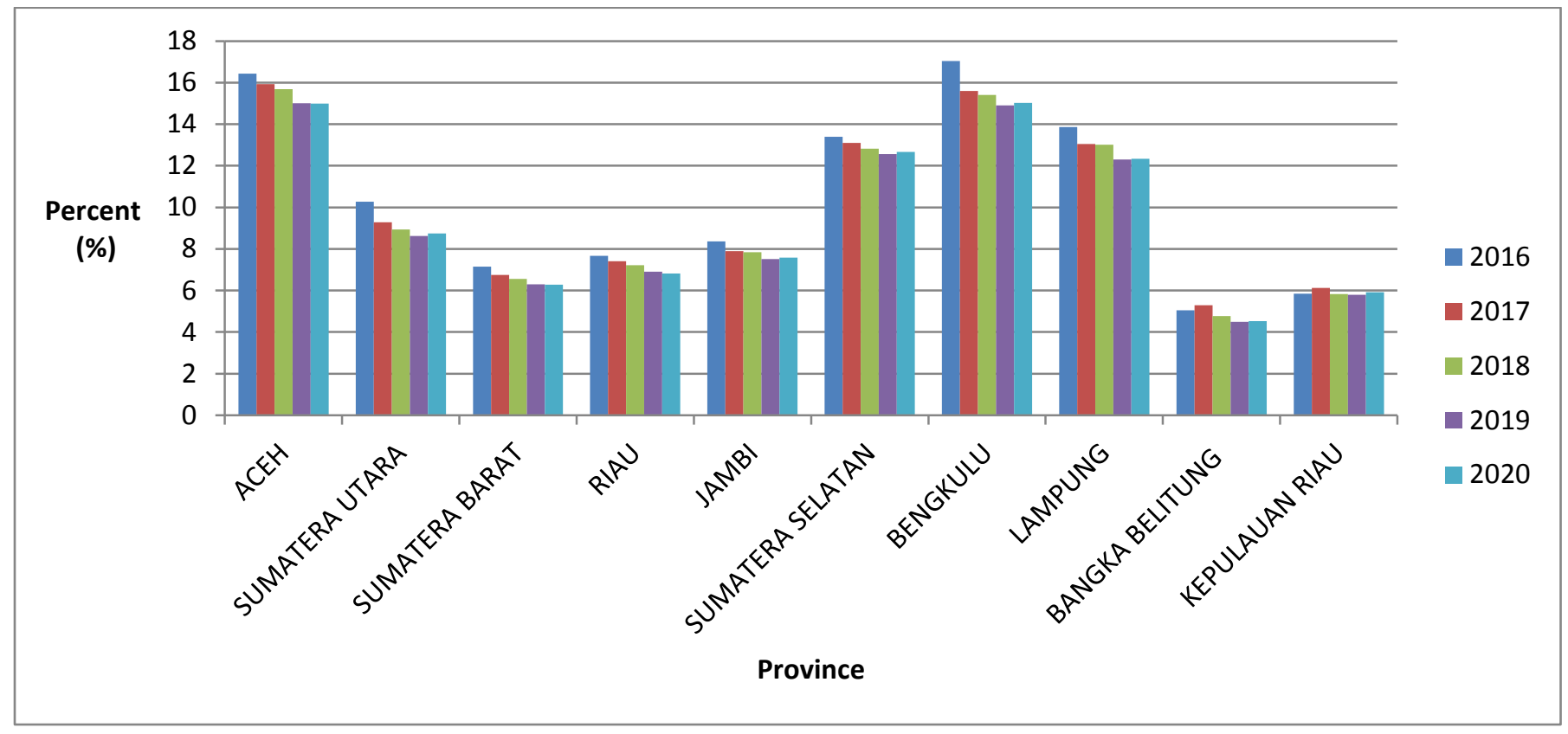

Figure 1. Poverty Rate in Sumatera Island 2016-2020 (Percent)

Poverty in Aceh varies by district/city. This is commonplace because each region has different potentials and policies.

Table 1. Poverty Rates for districts/cities in Aceh province 2015-2019

\begin{tabular}{llccccc}
\hline \multirow{2}{*}{ No } & \multicolumn{1}{c}{ Region Name } & \multicolumn{5}{c}{$\begin{array}{c}\text { Percentage of Poor Population by Regency / City } \\
\text { (Percent) }\end{array}$} \\
\cline { 3 - 7 } & \multicolumn{1}{c}{ ACEH } & $\mathbf{2 0 1 5}$ & $\mathbf{2 0 1 6}$ & $\mathbf{2 0 1 7}$ & $\mathbf{2 0 1 8}$ & $\mathbf{2 0 1 9}$ \\
\hline & & 17.08 & 16.73 & 16.89 & 15.97 & 15.32 \\
\hline 1 & Simeulue & 20.43 & 19.93 & 20.20 & 19.78 & 18.99 \\
\hline 2 & Aceh Singkil & 21.72 & 21.60 & 22.11 & 21.25 & 20.78 \\
\hline 3 & Aceh Selatan & 13.24 & 13.48 & 14.07 & 14.01 & 13.09 \\
\hline 4 & Aceh Tenggara & 14.91 & 14.46 & 14.86 & 14.29 & 13.43 \\
\hline 5 & Aceh Timur & 15.85 & 15.06 & 15.25 & 14.49 & 14.47 \\
\hline 6 & Aceh Tengah & 17.51 & 16.64 & 16.84 & 15.58 & 15,50 \\
\hline 7 & Aceh Barat & 21.46 & 20.38 & 20.28 & 19.31 & 18.79 \\
\hline 8 & Aceh Besar & 15.93 & 15.55 & 15.41 & 14.47 & 13.92 \\
\hline 9 & Pidie & 21.18 & 21.25 & 21.43 & 20.47 & 19.46 \\
\hline 10 & Bireuen & 16.94 & 15.95 & 15.87 & 14.31 & 13.56 \\
\hline 11 & Aceh Utara & 19.20 & 19.46 & 19.78 & 18.27 & 17.39 \\
\hline 12 & Aceh Barat Daya & 18.25 & 18.03 & 18.31 & 17.10 & 16.26 \\
\hline 13 & Gayo Lues & 21.95 & 21.86 & 21.97 & 20.70 & 19.87 \\
\hline 14 & Aceh Tamiang & 14.57 & 14.51 & 14.69 & 14.21 & 13.38 \\
\hline 15 & Nagan Raya & 20.13 & 19.25 & 19.34 & 18.97 & 17.97 \\
\hline 16 & Aceh Jaya & 15.93 & 15.01 & 14.85 & 14.16 & 13.36 \\
\hline 17 & Bener Meriah & 21.55 & 21.43 & 21.14 & 20.13 & 19.30 \\
\hline 18 & Pidie Jaya & 21.40 & 21.18 & 21.82 & 20.17 & 19.31 \\
\hline & & & & & & \\
\hline & & & & & & \\
\hline
\end{tabular}




\begin{tabular}{llccccc}
\hline 19 & Kota Banda Aceh & 7.72 & 7.41 & 7.44 & 7.25 & 7.22 \\
\hline 20 & Kota Sabang & 17.69 & 17.33 & 17.66 & 16.31 & 15.60 \\
\hline 21 & Kota Langsa & 11.62 & 11.09 & 11.24 & 10.79 & 10.57 \\
\hline 22 & Kota Lhokseumawe & 12.16 & 11.98 & 12.32 & 11.81 & 11.18 \\
\hline 23 & Kota Subulussalam & 20.39 & 19.57 & 19.71 & 18.51 & 17.95 \\
\hline
\end{tabular}

Source: Aceh Province Statistics, 2019

When viewed from a district/city level in Aceh, the majority of poverty levels are above the poverty in Aceh province. It can be seen that out of 23 districts/cities 17 districts/cities are in the chart above 15 percent and some are even above 20 percent. Then the remaining 6 city districts have a poverty rate below 15 percent.

If you look at the highest district/city poverty rate in 2015 and 2016, the highest poverty rate in Gayo Lues district was $21.95 \%$ then in 2016 it decreased to $21.86 \%$, then in 2017-2019 the poverty rate in Gayo lues district experienced a continuous decline, and the highest poverty rate in 2017-2019 occurred in Aceh Singkil district where in 2017 it was $22.11 \%$ then in 2017 it decreased from the previous year to $21.85 \%$ and lastly, in 2019, it continued to decline to $20.78 \%$.

Furthermore, the lowest poverty rate occurred in the city of Banda Aceh where the poverty rate fluctuated in 20152019. In 2015 it was $7.72 \%$, then in 2016, it decreased to $7.41 \%$. Furthermore, in 2017 there was a slight increase of only $0.03 \%$ to $7.44 \%$. Then in 2018, it decreased again to $7.25 \%$ and finally, in 2019 it also decreased to $7.22 \%$.

The challenge that must be faced by local governments is to promote sector development and economic activities that absorb a relatively high labor force. This needs to be done because with the increase in productivity which absorbs a lot of labor, there will be an increase in the welfare of the community (Garidzirai et al., 2019).

This is in line with research (Christiaensen and Kuhl, 2011) the effect of sectoral output on the number of poor people. Labor productivity and company efficiency are determinants of increasing potential economic sector output. (Murohman et al., 2016) stated that the sectors that have the highest forward and backward linkages are said to be sectors that have a domestic base both in terms of input and output so that these sectors are urgently needed in regional economic development sustainable.

Economic activities in Aceh consist of various economic sectors. The contribution of each sector to the Gross Regional Domestic Product (GRDP) is also different. This contribution can be seen in the Figure 2.

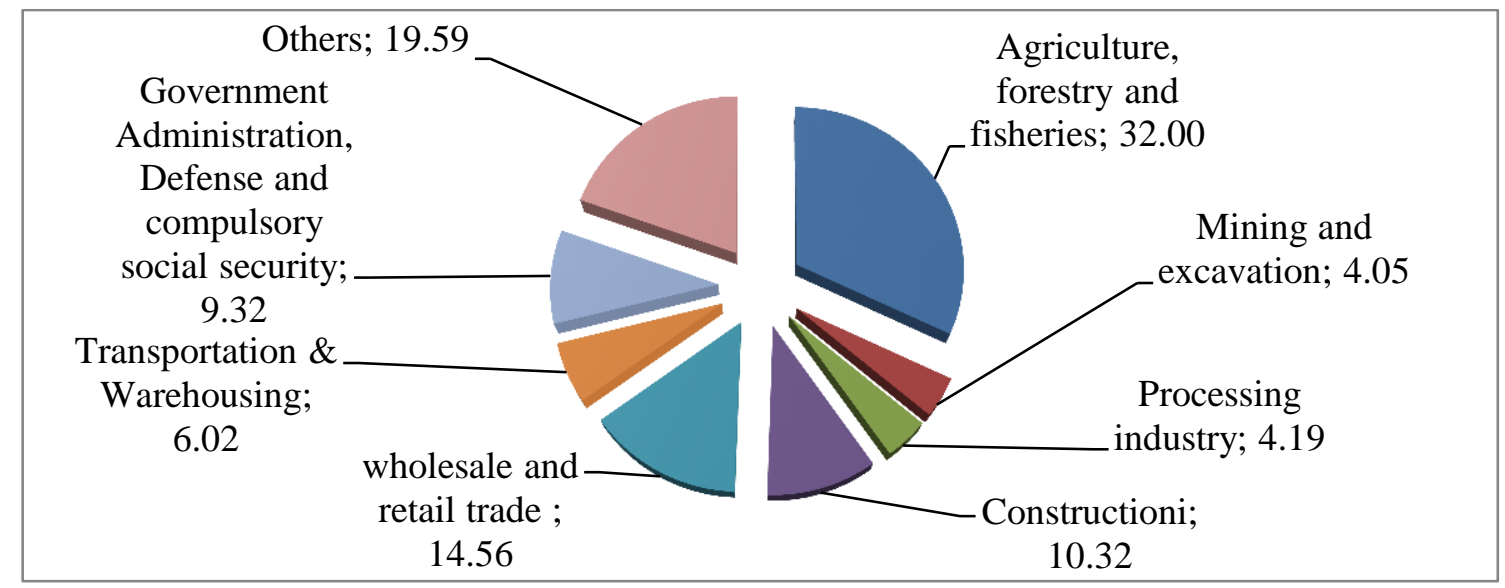

Figure 2. Contribution of the Economic Sector to Aceh's GRDP in 2020 (Percent)

Based on the Table 1, the sector with the largest contribution is used as a variable in this study. This variable is considered to have a good influence in reducing poverty levels.

Therefore, the researcher feels it is necessary to research the influence of the selected economic sector on poverty reduction in Aceh. The purpose of this study was to analyze the influence of the agricultural, trade, construction, and manufacturing sectors on poverty levels in Aceh. 


\section{Literature Review}

\subsection{Agricultural Sector}

Agriculture is the most important sector in the economy that supports life for the production of other sectors such as the fisheries sub-sector, the plantation sub-sector, the livestock sub-sector because it utilizes biological resources by humans to produce food, industrial raw materials or energy sources, and environmental management. (Loayza and Raddatz, 2010).

The agricultural sector is a strategic sector and plays an important role in the national economy and the survival of society, especially in contributing to GDP, providing employment and domestic food supply (Pham and Riedel, 2019).

\subsection{Trade Sector}

The Trade Sector is an economic activity that is engaged in the supply and distribution of goods needed by society and industry through market mechanisms or special operations for goods needed by the community, both domestic trade and trade between countries or international trade (Mahembe et al., 2019).

This category includes economic activities/business fields in wholesale and retail trade (sales without technical changes) of various types of goods, and the provision of fees for services that accompany the sale of these goods. Both wholesale (wholesale trade) and retail sales are the final stages in the distribution of merchandise. This category also includes car and motorcycle repair shops (Ferreira and Ravallion, 2010).

\subsection{Construction Sector}

The construction sector is one of the strategic sectors in supporting the achievement of national development. This strategic position can be seen from the linkages with other sectors (Ferreira and Ravallion, 2010).

The contribution process of the construction sector is directly proportional to the process of economic progress in a region and creates an increasingly complex implementation process with interdependence between one party and another. The construction process is understood as structuring a process or method for building a building (Garidzirai and Paul, 2019).

\subsection{Processing Industry Sector}

Industrial activities are activities to change the form, both technically and chemically, from organic or inorganic materials into new products of higher value. This process can be done by machine or by hand, whether it is made in a factory or in a household. This includes the assembly of parts for industrial goods in factories such as car tools and electronics.

The Central Bureau of Statistics (BPS) defines the processing / processing industry as an economic activity that carries out the activity of transforming basic goods mechanically, chemically, or by hand into finished goods or semifinished goods or goods of less value into goods. Higher value, and closer to the end user (BPS, 2019).

The composition and output growth of the economic sector is important because it provides information about the economic sector that is effective in improving the economy. Furthermore, gradual economic growth will lead to a reduction in the level of poverty (Dewbre et al., 2011).

Independent Variable

Dependent Variable

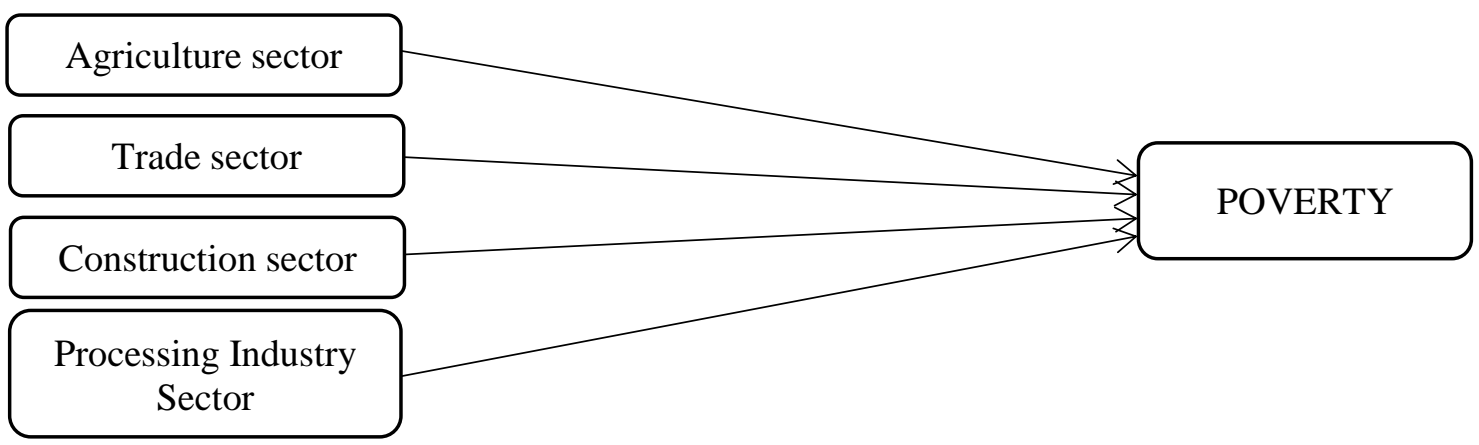

Figure 3. Conceptual Framework 
Therefore, the researcher feels it is necessary to conduct research on the influence of the selected economic sector on poverty reduction in Aceh. The purpose of this study was to analyze the influence of the agricultural, trade, construction and manufacturing sectors on poverty levels in Aceh.

Based on the variables previously described. To facilitate understanding in this study, a conceptual framework is shown in Figure 3.

\section{Materials and Methods}

\subsection{Materials}

The data structure used is panel data, namely 23 districts/cities in Aceh Province and the period 2010-2019. The independent variable in this study consists of the agricultural sector, the trade sector, the construction sector, and the manufacturing sector, while the dependent variable is poverty. As for the independent variable data used is the Percentage Distribution of Gross Regional Domestic Product (GRDP) 2010 series according to business fields and the dependent variable uses the percentage of poverty data. The data used in this study is secondary data obtained from the Central Statistics Agency (BPS).

The analysis used is panel data regression analysis. Panel data regression analysis is used to see the effect of certain economic sectors on poverty levels. Panel data regression models in this study are:

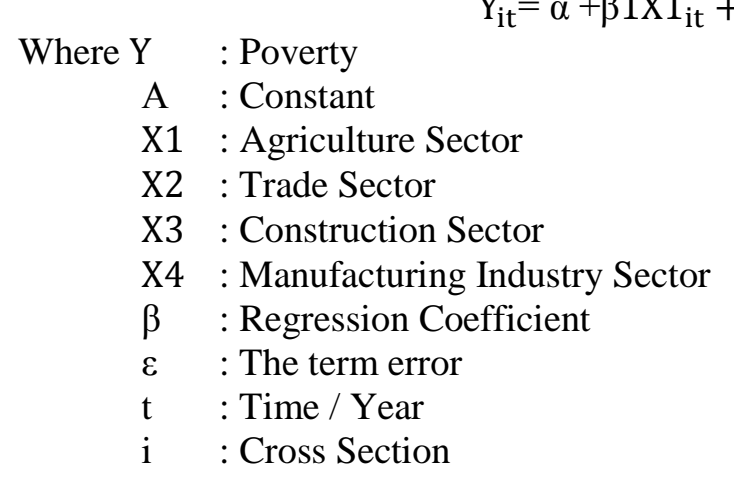

\subsection{Methods}

There are several stages in panel data regression:

\subsubsection{Estimation Method}

In the estimation method, the regression model using panel data is carried out through three approaches, namely (Kim et al., 2016).

\subsubsection{Common Effect Model}

This model does not pay attention to both the time dimension and the individual dimension, so it can be assumed that the behavior of company data is the same in various periods. This method can use the Ordinary Least Square (OLS) approach or the least-squares technique in estimating the panel data model.

\subsubsection{Fixed Effect Model}

In estimating panel data the Fixed Effect model uses dummy variable techniques to capture intercept differences between companies. However, the slope is the same between companies. This estimation model is often called the least squares dummy variable (LDSV) technique.

\subsubsection{Random Effect Model}

This model will estimate panel data where the disturbance variables may be interrelated over time and between individuals. In the random effect model, the difference in intercept is accommodated by the error terms of each company. The advantage of using this model is that it eliminates heteroscedasticity. This model is also called the Error Component Model (ECM) or the Generalized Least Square (GLS) technique.

\subsubsection{Model Selection}

When you want to choose the right model for managing panel data, several tests need to be done, namely (Khan and Muhammad, 2018). 


\subsubsection{Chow Test (F Statistical Test)}

The Chow test is a test to determine the fixed effect or common effect model that is most appropriate to use in estimating panel data. Decision making is done through the prob value. $F<$ critical limit, then reject $H O$ or choose fixed effect instead of common effect. Meanwhile, if the prob. $F>$ critical limit, then accept $H O$ or choose common effect instead of fixed effect.

\subsubsection{Hausman Test}

The Hausman test is a statistical test to choose whether a fixed effect or random effect model is most appropriate. Decision making is done if the value of the calculated chi-square $>$ chi-squares table or the chisquares probability value < significance level, then reject $H O$ or choose the fixed effect over the random effect. Then if the value of the calculated chi-square < chi squares table or the probability value of chi squares > significance level, then do not reject $H O$ or choose the random effect over the fixed effect.

\subsubsection{Classic Assumption Test}

The classical assumption testing used in linear regression with the Ordinary Least Squared (OLS) approach includes Linearity, Autocorrelation, Heteroscedasticity, Multicollinearity, and Normality tests. Even so, in panel data regression, not all classical assumption tests need to be done. The reasons are as follows:

1. The regression model is assumed to be linear so that the linearity test is almost unnecessary to be carried out on the linear regression model.

2. In terms of BLUE (Best Linear Unbias Estimator), the normality test is not included in it. Besides, several opinions do not require this requirement as an obligation to be fulfilled.

3. The autocorrelation test if it is carried out on cross-section or panel data will be useless, because autocorrelation will only occur in time series data.

4. When the linear regression model uses more than one independent variable, it is necessary to do a multicollinearity test. Because if there is only one independent variable, multicollinearity is impossible.

5. Data will contain heteroscedasticity, which usually occurs in cross-section data, while panel data is more directed towards cross-section data characteristics than time-series data.

From some of the descriptions above, it can be concluded that in the panel data regression model, the classic assumption tests that need to be used are only multicollinearity and heteroscedasticity tests. The following is an explanation of the Multicollinearity and Heteroscedasticity Test according to (Basuki and Nano, 2016):

\subsubsection{Multicollinearity Test}

Tests are conducted to see whether there is a high correlation between the independent variables in a multiple linear regression model. If there is a high correlation between the independent variables, then the relationship between the independent variables and the dependent variable will be disturbed. Pairwise correlation method decision making is carried out if the correlation value of each independent variable $<0.85$ means that $H O$ does not reject or there is no multicollinearity problem or the correlation value of each independent variable $>0.85$ then a reject $H O$ or multicollinearity problem occurs.

\subsubsection{Heteroscedasticity Test}

This test is carried out to see the variance inequality from the residuals of one observation to another. A regression model that meets the requirements if there is a similarity in variance from one observation residual to another is constant or is called homoscedasticity.The methods used in the heteroscedasticity test were White, Glejser, Breusch-Pagan-Godfrey, Harvey, and ARCH tests. Furthermore, the model will meet the requirements if the chi-square probability value of the regression model exceeds the alpha value of $0.5 \%$. If this is fulfilled, it can be said that the model does not contain heteroscedasticity (Khan and Muhammad, 2018).

\subsubsection{Hypothesis Testing}

\subsubsection{Test Coefficient of Determination (Adjusted)}

According to (Basuki and Nano, 2016) the coefficient of determination is used to measure how far the model's ability to explain variations of the dependent variable. Getting closer to number one means that almost all independent variables can provide the information needed to predict the variation in the dependent variable.

\subsubsection{Simultaneous Test (Test F)}

According to (Basuki and Nano, 2016) the F test is carried out to show whether all the independent or independent variables included in the model have a joint influence on the dependent or dependent variable. The formulation of the hypothesis is as follows. Ho is independent variable simultaneously does not affect the 
dependent variable and $\mathrm{Ha}$ is independent variable simultaneously affects the variable dependent. The test performance is as follows. $\mathrm{Ho}$ is accepted if the level of significance $>0.05$ and $\mathrm{Ha}$ is accepted if the level of significance $<0.05$.

\subsubsection{Partial Test (T-Test)}

According to (Rosadi, 2011) the T-test is carried out to determine how much influence each explanatory or independent variable has in explaining the dependent variable. The hypothesis formula used is as follows Ho: the independent variable has no significant effect on the variable dependent and $\mathrm{Ha}$ : the independent variable has a significant effect on the variable dependent. The test criteria are as follows. Ho is accepted if the level of significance $>0.05$ and $\mathrm{Ha}$ is accepted if the level of significance $<0.05$.

\section{Results and Discussion}

\subsection{Results}

\subsubsection{Estimation Model}

\subsubsection{Common Effect Model}

Estimation of this model is carried out using the CEM approach which assumes that the intercept and slope will remain throughout the time and unit. The estimation results using CEM are presented in the Table 2.

Table 2. Fixed Effect Model

\begin{tabular}{ccccc}
\hline Variable & Coefficient & Std. Error & t-Statistic & Prob. \\
\hline C & 13.23435 & 1.788083 & 7.401420 & 0.0000 \\
X1 & 0.161487 & 0.025120 & 6.428524 & 0.0000 \\
X2 & -0.147083 & 0.055799 & -2.635953 & 0.0090 \\
X3 & 0.145114 & 0.044420 & 3.266888 & 0.0013 \\
X4 & 0.050405 & 0.032171 & 1.566791 & 0.1186 \\
\hline
\end{tabular}

Based on the output in Table 2. Common Effect Model, it can be seen that only the X4 variable (Manufacturing Industry Sector) is not significant in the model because the p-value is greater than the $5 \%$ significant level. So that then the insignificant variables are excluded from the model one by one, then the FEM estimation results are as follows:

$$
\mathrm{Y}_{\mathrm{it}}=\beta_{\mathrm{oi}}+0.16 \mathrm{X} 1_{\mathrm{it}}-0.14 \mathrm{X} 2_{\mathrm{it}}+0.14 \mathrm{X} 3_{\mathrm{it}}+\varepsilon_{\mathrm{it}}+\ldots
$$

Based on the equation (2), it can be seen that the variables that affect poverty are the Agricultural Sector (X1), the Trade Sector (X2), and the Construction Sector where the coefficient value is negative. This means:

1. $0.16 \mathrm{X}_{\mathrm{it}}$ : If the agricultural sector increases by IDR $1,000,000$ ceteris paribus, it will increase the poverty rate by $0.16 \%$.

2. $-0.14 \mathrm{X} 2_{\mathrm{it}}$ : If the trade sector increases by IDR $1,000,000$ ceteris paribus it will reduce the poverty rate by $0.14 \%$.

3. $0.14 \mathrm{X}_{\text {it }}$ : If the construction sector increases by IDR $1,000,000$ ceteris paribus, it will increase the poverty rate by $0.14 \%$.

\subsubsection{Fixed Effect Model}

Based on the output in the Table 3, the fixed-effect model shows that all independent variables have a significant effect on the dependent variable. The following are the results of the FEM estimation as follows:

$$
\mathrm{Y}_{\mathrm{it}}=\beta_{\mathrm{oi}^{-}} 0.71 \mathrm{X} 1_{\mathrm{it}^{-}} 0.48 \mathrm{X} 2_{\mathrm{it}^{-}}-0.51 \mathrm{X} 3_{\mathrm{it}^{-}}-0.67 \mathrm{X} 4_{\mathrm{it}}+\varepsilon_{\mathrm{it}}+\ldots
$$

Based on the model equation (3), it can be seen that the variables that affect poverty are the agricultural sector, the construction sector, and the manufacturing sector, where the coefficient is negative. It means:

1. $-0.71 \mathrm{X} 1_{\text {it }}$ If the agricultural sector increases by IDR $1,000,000$ ceteris paribus, it will reduce the poverty rate by $0.71 \%$. 
2. $-0.48 \mathrm{X}_{2}$ it: If the construction sector increases by IDR $1,000,000$ ceteris paribus, it will reduce the poverty rate by $0.48 \%$.

3. $-0.51 \mathrm{X}_{\mathrm{it}}$ : If the construction sector increases by IDR $1,000,000$ ceteris paribus, it will reduce the poverty rate by $0.51 \%$.

4. $-0.67 \mathrm{X}_{\mathrm{it}}$ : If the manufacturing sector increases by $\mathrm{Rp} 1,000,000$ ceteris paribus, it will reduce the poverty rate by $0.67 \%$.

Table 3. Fixed Effect Model

\begin{tabular}{ccccc}
\hline Variable & Coefficient & Std. Error & t-Statistic & Prob. \\
\hline C & 31.57470 & 0.945253 & 33.40343 & 0.0000 \\
X1 & -0.710652 & 0.025565 & -1.981326 & 0.0489 \\
X2 & -0.481607 & 0.088179 & -0.925471 & 0.3558 \\
X3 & -0.517212 & 0.073178 & -12.53398 & 0.0000 \\
X4 & -0.671318 & 0.021545 & -7.951713 & 0.0000 \\
\hline
\end{tabular}

\subsubsection{Random Effect Model}

Based on the output results in the Table 4 Random effect model, it can be seen that the X1 variable (Agricultural Sector) is not significant in the model because the $p$-value is greater than the 5 percent significant level. So that insignificant variable is excluded in the model, then the REM estimation results are as follows:

$$
\mathrm{Y}_{\mathrm{it}}=\beta_{\mathrm{oi}^{-}} 0.41 \mathrm{X} 2_{\mathrm{it}^{-}} 0.40 \mathrm{X} 3_{\mathrm{it}^{-}} 0.14 \mathrm{X} 4_{\mathrm{it}}+\varepsilon_{\mathrm{it}^{+}}{ }^{\ldots}
$$

Based on the model equation above, it can be seen that the variables that affect poverty are the trade sector, the construction sector, and the manufacturing sector, where the coefficient value is negative. This means:

1. $-0.41 \mathrm{X} 2_{\mathrm{it}}$ : If the trade sector increases by IDR $1,000,000$ ceteris paribus it will reduce the poverty rate by $0.41 \%$.

2. $-0.40 \mathrm{X} 3_{\mathrm{it}}$ : If the construction sector increases by IDR $1,000,000$ ceteris paribus it will reduce the poverty rate by $0.40 \%$.

3. $-0.14 \mathrm{X}_{\mathrm{it}}$ : If the manufacturing sector increases by IDR $1,000,000$ ceteris paribus it will reduce the poverty rate by $0.14 \%$.

Table 4. Random Effect Model

\begin{tabular}{ccccc}
\hline Variable & Coefficient & Std. Error & t-Statistic & Prob. \\
\hline $\mathrm{C}$ & 30.36298 & 1.852698 & 16.38853 & 0.0000 \\
\hline $\mathrm{X} 1$ & -0.037849 & 0.032731 & -1.156368 & 0.2488 \\
\hline $\mathrm{X} 2$ & -0.418171 & 0.084314 & -4.959661 & 0.0000 \\
\hline $\mathrm{X} 3$ & -0.404647 & 0.079133 & -5.113488 & 0.0000 \\
\hline $\mathrm{X} 4$ & -0.142623 & 0.033938 & -4.202438 & 0.0000 \\
\hline
\end{tabular}

\subsubsection{Model Selection}

\subsubsection{Chow test}

Chow test is used to determine which model is better to use, namely between CEM or FEM.

Table 5. Chow Test Results

\begin{tabular}{cccc}
\hline Effects Test & Statistic & d.f. & Prob. \\
\hline Cross-section F & 127.554744 & $(22.203)$ & 0.0000 \\
\hline
\end{tabular}

Based on Table 5, the $p$-value in Cross-section $\mathrm{F}$ is 0.000 where the $p$-value is smaller than the significance level value $(\alpha=0.05)$, so $H O$ is rejected. This means that a better model to use is the Fixed Effect Model (FEM). 


\subsubsection{Hausman test}

The Hausman test is used to determine which model is better to use, namely between FEM or REM.

Table 6. Hausman Test Results

\begin{tabular}{cccc}
\hline Test Summary & Chi-Sq. Statistic & Chi-Sq. d.f. & Prob. \\
\hline Period random & 122.097886 & 4 & 0.0000 \\
\hline
\end{tabular}

Based on Table 6 , the p-value in Cross-section F is 0.000 where the $p$-value is smaller than the significance level value $(\alpha=0.05)$, so H0 is rejected. This means that a better model to use is the Fixed Effect Model (FEM).

\subsubsection{Hypothesis Testing}

After selecting the right FEM, a panel data regression equation is tested which consists of the simultaneous test (Ftest), partial test (T-test), and coefficient of determination.

\subsubsection{Simultaneous Test (F-Test)}

The $\mathrm{F}$ test is used to measure whether the independent variables together significantly influence the dependent variable.

Table 7. F-Test Results

\begin{tabular}{llll}
\hline R-squared & 0.939620 & Mean dependent var & 24.41517 \\
\hline Adjusted R-squared & 0.931887 & S.D. dependent var & 14.72111 \\
\hline S.E. of regression & 1.391693 & Sum squared resid & 393.1722 \\
\hline F-statistic & 121.5017 & Durbin-Watson stat & 0.718858 \\
\hline Prob(F-statistic) & 0.000000 & & \\
\hline
\end{tabular}

Based on Table 7, it is known that the $p$-value is smaller than the significance level value $(\alpha=0.05)$ so that $H O$ is rejected. This means that the independent variables jointly affect the dependent variable.

\subsubsection{Partial Test (t-test)}

The t-test is used to determine how far an independent variable can individually explain the dependent variable. Based on the Figure, all variables have a $p$-value less than the significance level value $(\alpha=0.05)$, so $H O$ is rejected. This means that the independent variables individually affect the dependent variable.

Table 8. T-Test Results

\begin{tabular}{ccccc}
\hline Variable & Coefficient & Std. Error & t-Statistic & Prob. \\
\hline $\mathrm{C} 1$ & 31.57470 & 0.945253 & 33.40343 & 0.0000 \\
\hline $\mathrm{X} 1$ & -0.710652 & 0.025565 & -1.981326 & 0.0489 \\
\hline $\mathrm{X} 2$ & -0.481607 & 0.088179 & -0.925471 & 0.3558 \\
\hline $\mathrm{X} 3$ & -0.517212 & 0.073178 & -12.53398 & 0.0000 \\
\hline $\mathrm{X} 4$ & -0.671318 & 0.021545 & -7.951713 & 0.0000 \\
\hline
\end{tabular}

Based on Table 8, all variables have a $p$-value less than the significance level value $(\alpha=0.05)$, so $H O$ is rejected. This means that the independent variables individually affect the dependent variable.

\subsubsection{Coefficient of Determination}

The coefficient of determination or commonly denoted R2 is used to measure how much the ability of the independent variable to explain the dependent variable.

Based on Table 9, the Adjusted R-squared value in the panel data regression model using the fixed effects model method with individual effects (cross-section) is 0.931887 . This means that the variation in the value of the independent variable of $93.18 \%$ can be mentioned by the regression model, while the remaining $6.82 \%$ consists of other factors not included in the model. 
Table 9. Results of the coefficient of determination

\begin{tabular}{llll}
\hline R-squared & 0.939620 & Mean dependent var & 24.41517 \\
\hline Adjusted R-squared & 0.931887 & S.D. dependent var & 14.72111 \\
\hline S.E. of regression & 1.391693 & Sum squared resid & 393.1722 \\
\hline F-statistic & 121.5017 & Durbin-Watson stat & 0.718858 \\
\hline Prob(F-statistic) & 0.000000 & & \\
\hline
\end{tabular}

\subsubsection{Classic Assumption Test}

\subsubsection{Multicollinearity Test}

Test to see if anyone does not know what is high between the independent variables in a multiple linear regression model. If there is a high level of availability between the independent variables, then the relationship between the independent variables and the dependent variable will be disturbed.

Table 10. Multicollinearity Test Results

\begin{tabular}{ccccc}
\hline & $\mathrm{X} 1$ & $\mathrm{X} 2$ & $\mathrm{X} 3$ & $\mathrm{X} 4$ \\
\hline $\mathrm{X} 1$ & 1.000000 & -0.648343 & -0.362729 & -0.384917 \\
$\mathrm{X} 2$ & -0.648343 & 1.000000 & 0.099137 & 0.129243 \\
X3 & -0.362729 & 0.099137 & 1.000000 & -0.067584 \\
X4 & -0.384917 & 0.129243 & -0.067584 & 1.000000 \\
\hline
\end{tabular}

Based on the Table 10, it can be seen that all probability value variables do not exceed the value 0.8 so that it means that all variables are free from multicollinearity. Thus, it can be concluded that there is no correlation between the independent variables in multiple regression.

\subsubsection{Heteroscedasticity test}

Test to see if there is an inequality of variance from the residuals of one observation to another.

Table 11. Heteroscedasticity Test Results

\begin{tabular}{ccccc}
\hline Variable & Coefficient & Std. Error & t-Statistic & Prob. \\
\hline C & 1.911841 & 0.925769 & 2.065137 & 0.0402 \\
X1 & -0.011748 & 0.025812 & -0.455144 & 0.6495 \\
X2 & -0.065555 & 0.073490 & -0.892021 & 0.3734 \\
X3 & 0.053812 & 0.057735 & 0.932054 & 0.3524 \\
X4 & -0.024721 & 0.020000 & -1.236092 & 0.2179 \\
\hline
\end{tabular}

Based on the data above, it can be seen that the probability value of all variables is greater than the significance level value $(\alpha=0.05)$ so that it can show that the data is free from heteroscedasticity.

\subsection{Discussion}

\subsubsection{Agriculture Sector on Poverty}

The test results found that the reduction in the poverty rate is simultaneously influenced negatively by the agricultural sector, trade sector, construction sector, and manufacturing industry. The test results show that the four sectors show a statistically significant effect on poverty levels.

The agricultural sector has a coefficient of -0.71065 with a probability of 0.049 so that if the agricultural sector increases by IDR $1,000,000$ ceteris paribus, it will reduce the poverty rate by -0.71 percent. In many developing countries, almost all studies provide empirical support regarding the view that the agricultural sector has become the main driver of poverty reduction like a study conducted by (Dewbre, Sorescu S, 2011) and (Montalvo and Ravallion, 2010). Although this may occur for a variety of reasons including the type of agriculture, agricultural growth rates, public and private investment, and government policy itself (Grewal et al., 2012), in some predominantly poor African countries, agricultural productivity enhancement interventions reduce poverty levels substantially and sustainably (Mwabu, 2016). Furthermore, in the Southeast Asia region, the agricultural sector has contributed to the 
Gross Domestic Product (GDP) of more than 10 percent and employs more than a third of the population (Fan, Z. and Zhuang, J, 2009).

\subsubsection{Trade Sector on Poverty}

The trade sector has a coefficient of -0.4816 with a probability of -0.036 so that if the construction sector increases by IDR $1,000,000$ ceteris paribus, it will reduce the poverty rate by 0.48 percent. Following the World Trade Organization, 2018 Economic literature has shown that trade openness is the key to poverty reduction. In general, trade affects the income of the poor through various alternatives such as the effects of economic growth, price movements, macro stability of government income (Mahembe et al., 2019).The effect of trafficking on the poor depends to a large extent on the specific mechanisms in places such as manufacturing competitions and factories where the poor are working.

\subsubsection{Construction Sector on Poverty}

Furthermore, the construction sector has a coefficient of -0.517 with a probability of 0.00 so that if the construction sector increases by $\mathrm{Rp}$. The $1,000,000$ ceteris paribus will reduce the poverty rate by $0.51 \%$.

In accordance with the research (Loayza and Raddatz, 2010), there is evidence that not only the measure of economic growth but also its composition is important for poverty alleviation, with the largest contribution from unskilled labor-intensive sectors The results are strong on the effects of outliers, endogeneity issues, alternative explanations, and various measures of poverty. Following the theory that has been explained, the construction sector is directly proportional to the process of economic progress in a region and creates an increasingly complex implementation process with interdependence between one party and another.

\subsubsection{Processing Industry Sector on Poverty}

Interestingly, the manufacturing sector has a higher impact on poverty than the trade and construction sectors, which contribute more to Aceh's economy. The construction sector has a coefficient of -0.671 with a probability of 0.00 so that the processing industry sector increases by Rp.1,000,000 ceteris paribus, which will reduce the poverty rate by $0.67 \%$.

This is by the results that have been done previously by Thu Hang (Pham and Riedel, 2019) regarding chemistry in Vietnam. Where most of the poor are in rural and informal urban areas. This has resulted in the agricultural sector still having an important role in poverty reduction. This is also the case in Aceh Province, where the population is poorer and mostly in rural areas.

The high influence of the manufacturing sector on poverty shows that the manufacturing sector is still developing, even though the raw materials are good from the agricultural side, but plantations are sufficiently available in Aceh. As we know, Aceh is known as an area rich in natural resources that other regions don't have. This is a great potential for the Aceh economy.

Previous research has been conducted (Murrohman and Asmara, 2016) which states that the development of the industrial sector is a policy that must be carried out. The industrial sector has a role in improving the economy and alleviating poverty. Industrial development will have an impact on labor absorption and labor mobilization from other sectors. Pham and Riedel (2019) the proportion of the industrial sector and the agricultural sector has a major impact on poverty reduction.

\section{Conclussion}

Based on the results of panel data regression, all economic sectors in this study, namely the agricultural, trade, construction, and manufacturing sectors have a significant negative effect on poverty.

The agricultural sector partially has a negative and significant impact on poverty levels in Aceh. This can be seen from the coefficient X1 value of -0.710652 , meaning that if the agricultural sector increases by Rp. 1,000,000 ceteris paribus, it will reduce the poverty rate by $0.71 \%$.

The trade sector partially has a negative and significant impact on poverty levels in Aceh. This can be seen from the coefficient X1 value of -0.481607 , meaning that if the agricultural sector increases by Rp.1,000,000 ceteris paribus, it will reduce the poverty rate by $0.48 \%$.

The construction sector partially has a negative and significant impact on poverty levels in Aceh. This can be seen from the coefficient value of $\mathrm{x} 1$ of -0.517212 , meaning that if the agricultural sector increases by Rp. 1,000,000 ceteris paribus, it will reduce the poverty rate by $0.51 \%$.

The manufacturing sector has a partially negative and significant impact on poverty levels in Aceh. . This can be seen from the coefficient $\mathrm{x} 1$ value of -0.671318 , meaning that if the processing industry sector increases by Rp. $1,000,000$ ceteris paribus, it will reduce the poverty rate by $0.67 \%$.

The agriculture, trade, construction, and manufacturing sectors simultaneously have a negative and significant impact on poverty levels in Aceh. This can be seen from the F test probability of 0.00 and it is $<0.05$. 
However, out of the four economic sectors in this study, the manufacturing sector shows a greater influence even though it has a small contribution to the economy in Aceh. Therefore, the development of the industrial sector is a must-do policy. The industrial sector has a role in improving the economy and alleviating poverty.

Industrial sector development is a policy that must be carried out. The industrial sector has a role in improving the economy and alleviating poverty, for example in terms of converting semi-finished goods to finished products. Industrial development will have an impact on labor absorption and labor mobilization from other sectors. Labor as a production factor in the industrial sector must be equipped with education and training so that income increases in return for production factors. This in turn will have an impact on people's productivity and will gradually increase people's income, reduce unemployment and reduce poverty.

\section{References}

Arham, M. A., Fadhli, A., and Dai, S. I. (2020). Does Agricultural Performance Contribute to Rural Poverty Reduction in Indonesia?. Journal of Economics and Policy, 13(1), 69-83.

Badan Pusat Statistik (2019). Produk Domestik Regional Bruto Menurut Lapangan Usaha 2015-2019. Banda Aceh: BPS Provinsi Aceh.

Badan Pusat Statistik (2020). Provinsi Aceh dalam Angka 2020. Banda Aceh: BPS Provinsi Aceh.

Basuki, T. A., and Prawoto, N. (2016). Analisis Regresi Dalam Penelitian Ekonomi\& Bisnis: Dilengkapi Aplikasi SPSS \& EVIEWS. Depok: PT Rajagrafindo Persada.

Christiaensen, L., Demery, L., and Kuhl, J. (2011). The (evolving) role of agriculture in poverty reduction-an empirical perspective. Journal of Development Economics, 96(2). 239-254.

Dewbre, J., Godoy, D. C., and Sorescu, S. (2011). Agricultural Progress and Poverty Reduction: OECD Food, Agriculture and Fisheries Working Papers. Paris (FR):OECD Food, Agriculture and Fisheries Papers, 49, 1-58.

Fan, Z. and Zhuang, J. (2009). Agricultural Impact of Climate Change: A General Equilibrium Analysis with Special Reference to Southeast Asia, ADBI Working Paper No. 131. Asian Development Bank, Mandaluyong City.

Ferreira, F., Leite, P., and Ravallion, M. (2010). Poverty reduction without economic growth? Explaining Brazil's poverty dynamics, 1985-2004. Journal of Development Economics, 93(1), 20-36.

Garidzirai, R., Meyer, D. F., and Muzindutsi, P. F. (2019). The Impact of Economic Sectors on Local Economic Development. Rufaro. International Journal of Economics And Finance Studies, 11(2), 1-476.

Grewal, B., Grunfeld, H., and Sheehan, P. (2012). The contribution of Agricultural growth to poverty reduction. Canberra: ACIAR.

Khan, Farzana Naheed and Muhammad Tariq Majeed. (2018).Globalization and Poverty Nexus: A Panel Data Analysis. Forman Journal of Economic Studies, 14, 143-174.

Kim, Namhyun ., HakJun Song and Ju Hyun Pyun. (2016). The relationship among tourism, poverty, and economic development in developing countries A panel data regression analysis. Tourism Economics, 22(6), 1174-1190.

Loayza, N., and Raddatz, C. (2010). The composition of growth matters for poverty alleviation. Journal of Development Economics, 93, 137-151.

Mahembe, Edmore and Nicholas Mbaya Odhiambo., Christian Nsiah. (2019). Foreign aid, poverty and economic growth in developing countries: A dynamic panel data causality analysis. Cogent Economics \& Finance, 7(1), 1-17.

Montalvo, J., and Ravallion, M. (2010). The pattern of growth and poverty reduction in China. Journal of Comparative Economics, 38, 2-16.

Murohman, M. P., \& Asmara, A. (2016), Pengembangan Sektor Ekonomi dan Pengentasan Kemiskinan di Kalimantan Barat. Jurnal Ekonomi dan Kebijakan Pembangunan, 5(1), 45-62.

Mwabu, (2016) Germano. Agriculture Productivity and Poverty Eradication In Africa. Kenya: University of Nairobi. 
Nargis, F. (2019). Poverty Reduction and Human Development: Impact of ENRICH Programme on Income Poverty in Bangladesh. Indian Journal of Human Development, 13(1), 13-31.

Pérez de la Fuente, B. (Oct. 2016). Economic Growth and Poverty Reduction in a Rapidly Changing World. European Economy. Economic Brief, 19, 2-17.

Pham, T. H., and Riedel, J. (2019). Impacts of the sectoral composition of growth on Poverty reduction in Vietnam. Journal of Economics and Development, 21(2), pp. 213-222.

Sehrawat, M. and Giri, A.K. (2016). Financial development and poverty reduction: panel data analysis of South Asian countries. International Journal of Social Economics, 43(4), 400-416.

Singh, P. K., and Chudasama, H. (2020). Evaluating Poverty Alleviation Strategies in a Developing Country. PLoS One, 15(1), 123.

World Trade Organization. Trade and Poverty Reduction New Evidence Of Impacts In Developing Countries. United Nations: World Bank Group, 2018.

Zakaria, Z., Zulham, T., and Gunawan, E. (2019). Analisis Struktur Ekonomi Kabupaten Aceh Besar. Jurnal Perspektif Ekonomi Darussalam, 4(1), 44-55. 